\title{
Educational Preparation and Quality of Trainings Attended towards Teachers' Capability in Research- Based Instructional Materials Development
}

\author{
Gladys L. Lagura And Emybel M. Alegre \\ gladys.lagura@yahoo.com \\ College of Education, Caraga State University \\ Ampayon, Butuan City, Agusan del Norte \\ Philippines \\ DOI: 10.29322/IJSRP.10.06.2020.p10283 \\ http://dx.doi.org/10.29322/IJSRP.10.06.2020.p10283
}

\begin{abstract}
Professional development is considered essential for the quality education. Training is one of the professional developments that play a decisive role in the achievement of quality education. This paper determines the extent of the training attended, in-service and training from other institutions as to the content, nature and scope of training. This also determines the extent of training attended from other institution as to quality of training. The study further examines the relationship between the training attended and Teachers' capability on Research-Based Instructional Materials Development (RB-IMD) as to needs analysis and development process. Descriptive correlation research design was employed involving 115 participants who participated in the teachers' training in research-based instructional materials development. Findings have shown that teacher participants had attended seminar-workshop, related to instructional materials development in school, district, division and other institution. Moreover, Teachers' Capability on Research-Based Instructional Materials Development (RB-IMD) as to needs analysis and instructional materials development process has a significant positive correlation with the extent of their in-service training as to nature and scope of training. For the training attended from other institution as to content and scope of training, and in the quality of teachers' training attended as to the design of learning, it has a significant positive correlation. Data further revealed that the quality of teachers' training attended as to the assessment of learning has a significant positive correlation with the teachers' capability on RB-IMD as to needs analysis and IMs development. It is recommended to enhance and continue developing teachers' capability in research-based instructional materials development through further training, towards sustainable quality education.
\end{abstract}

Keywords: Professional Development, Instructional Materials Development, Research-Based, Teachers' Capability,

\section{Introduction}

Professional development for teachers is a critical vehicle through which to improve teaching and, in turn, to improve student achievement (Petrie, K., \& McGee, C. 2012). To improve teaching and improve student achievement is the mission of the educational institution. Garet, M. S., Porter, A. C., Desimone, L., Birman, B. F., \& Yoon, K. S. (2001) state the needs of practical Professional development sustainability, with intensive learning experiences. Teachers need to experience 'on-going sessions of learning, collaboration, and application, accompanied by the school- and classroom-based support, over an ample period to incorporate new behaviors fully into a teacher's repertoire' (Killion, 2006) as cited by Petrie, K., \& McGee, C. (2012).

Recognition of the importance of teachers to student outcomes has resulted in a shift in aid investment from a primary focus on increasing access to education to increase support for interventions aimed at improving teacher quality in developing countries (Colclough, 2005). Barber \& Mourshed (2007) opined that the quality of an education system could not exceed the quality of its teachers. Teacher quality and capability, as measured by skills, knowledge, and qualifications, play a decisive role in students' progress (Hanuchek,2003; Barber \& Mourshed, 2007; Varga, 2007). Besides, the teacher has a complex task that is to 
deliver the knowledge that brings impact to student performance towards lifelong learning, this call for a teacher who has a capability that models lifelong learning, a teacher that engages in on-going professional development and applies it to teaching practice. Therefore engaging them training for professional development can boost their performance towards quality teaching and improve their teaching capability.

Professional development has attracted increasing attention. Faced with rapid change, demands high standards and calls for improving quality teachers, hence a need as never before, to update and improve their skills through professional development. Therefore, for a teacher to fulfill his/her professional function in a given domain, a synthesis of knowledge, attitudes, and practical skills is needed (Falus, 2002). To realize these needs, part of being an effective teacher involves understanding how an individual or adults learn best. Teachers are adult learners, and their professional development is a form of adult education, which shifts the focus of professional development to the needs of teachers and the different contexts in which they learn and teach (King \& Lawler, 2003).

Moreover, Republic Act No. 10912, Resolution No. 2016-990 (Continuing Professional Development Act of 2016) now declared the policy of the State to promote and upgrade the practice of professions in the country. Towards this end, the State shall institute measures that will continuously improve the competence of the professionals following international standards of practice, thereby, ensuring their contribution in uplifting the general welfare, economic growth, and development of the nation."

Teachers' training on the development of outcomes-based instructional materials (OBIMs) for K-12 education in Caraga and enhancement of their research capability, is hoped to provide relief among teacher implementers and meaningful experience among learners. It is the extension project of the College of Education, Caraga State University, Ampayon, Butuan City. This project is aimed to capacitate teachers in the implementation of K-12 education in Caraga; that is, for teachers to evolve researchbased instructional materials that will enhance learning experiences of learners along with the spiraling progression approach by Bruner as cited by (Howard, J. (2007).

This research examined teacher's capability in research-based instructional materials development, to examine the learning experience and the design and delivery of this learning among the teacher participants or the adult learners of the teachers training offered by the College of Education, Caraga State University, Ampayon, Butuan City, Philippines. Through examining these experiences and teachers capability in research-based instructional materials development, this study can explore the needs of teachers and the learning contexts that will help them grow towards continuing professional development.

\section{The Objectives of the Study}

The study attempted to determine the extent of the training attended as part of the continuing professional development in determining Teachers' capability in Research-Based Instructional Materials Development (RB-IMD). Specifically, to determine the extent of trainings attended; in-service training and training from other institution as to the content, nature and scope. Examines the quality of training attended from other institution as to the design and assessment of learning. And determine 
the relationship between the training attended, in-service and from other institution to Teachers' capability on Research-Based Instructional Materials Development (RB-IMD) needs analysis and development process.

\section{The framework of the Study}

This study anchored on Bandura's social cognitive theory (1986), Knowles' theory of andragogy (2012) and several theories of learning and adult development that was identified by Trotter (2006) by themes which are relevant for designing teacher professional development.

The Social cognitive theory of Bandura (1986) as cited by Atilano, M.M. (2018) revolves around the notion that learning correlates to the observation of role models, that individuals possess a self-system that enables them to exercise a measure of control over their thoughts, feelings, motivation, and actions. This learning will motivate their capability to influence their cognitive processes and actions and thus alter their environments.

Knowles theory of andragogy, on the other hand, is described as "the art and science of helping adults learn." Knowles espouses the idea that teachers are adult learners who are expected to be self-directed and to take responsibility for their decisions.

Trooter (2006) outlines several theories of learning and adult development that are relevant for designing teacher professional development. The following are identified themes; Adults come to learning with experiences that utilize as resources for new learning, and adults should choose their learning opportunities based on interest and their own classroom experiences/needs. "Active learning" suggests moving away from traditional learning models that are generic and lecture based toward models that engage teachers directly in the practices they are learning and, preferably, are connected to teachers' classrooms and students.

Greenleaf, C. L., Litman, C., Hanson, T. L., Rosen, R., Boscardin, C. K., Herman, J.,\& Jones, B. (2011) describe an active teacher professional learning model that improved student science learning.44 California high school biology teachers participated in PD integrating academic literacy and biology instruction through a program called Reading Apprenticeship. The PD was inquiry-based, subject focused, collaborative, and designed to address teachers' conceptual understandings as well as pedagogical content knowledge. Each session was designed to immerse the teachers in the types of learning activities and environments they would then create for their students.

Based on the theories presented, the following are the conceptual framework of the study. The dependent variables are the continuing professional activities like the in-service education of the participants, which measures the content, nature, and scope of training attended. The Quality of training attended are supported by the indicators on the content, nature, and scope of training attended and the quality as to the design and assessment of learning. The independent variables are teacher's capability on research-based instructional materials development as to needs analysis and instructional materials development process. 
Methodology

The study used a descriptive and correlational method. The choice is base on the fact that this research undertaking was a fact-finding. It was a systematic attempt to analyse and interpret the teachers' capability in research-based instructional materials development as to needs analysis and instructional materials development process as influenced by in-service training, training from other institution and quality of training attended. On top of them, there is a significant relationship determined. The respondents of the study involved 115 teachers who attended the teachers training under the extension project of the College of Education, Caraga State University, Ampayon, Butuan City. The research instruments employed in the study consisted of three parts. Part 1 is the in-service training attended as to the content, nature and scope, Part II focuses on training from other institution attended as to content, nature and scope. It also measure the quality of training attended from other institution as to the design and assessment of learning, and Part III comprises questions on teacher's capability in research-based instructional materials development as to needs analysis and instructional materials development process. The study used the following statistical tools; quasi-statistics, is employed on nominal variables and qualitative responses to generate corresponding values such as counts and percentage, mean is used to determine the quality of training attended as to the design and assessment of learning, and SpearmanRho Correlation used since the independent variables yielded non-normal data. In the analysis, Likert scales responses convert into ranks.

\section{Results and Discussion}

\section{The extent of in-service training}

The content of training attended, are pedagogy-oriented (28.7\%), content-oriented (24.3\%) and leadership and management-oriented $(24.3 \%)$. This significant result is essential to visualize the effects of these capability building to students achievements. In the study of Zuzovsky, R. (2003) reveals that regular participation of teachers in content-oriented professional development positively affects with low or medium academic aspirations and has no or negative effect on the achievement of students with high academic aspirations. In the study of Garet, Porter, Desimone, Birman, \& Yoon, (2001), which state teachers themselves report that professional development focused on content knowledge contributes to changes in instructional practice. 


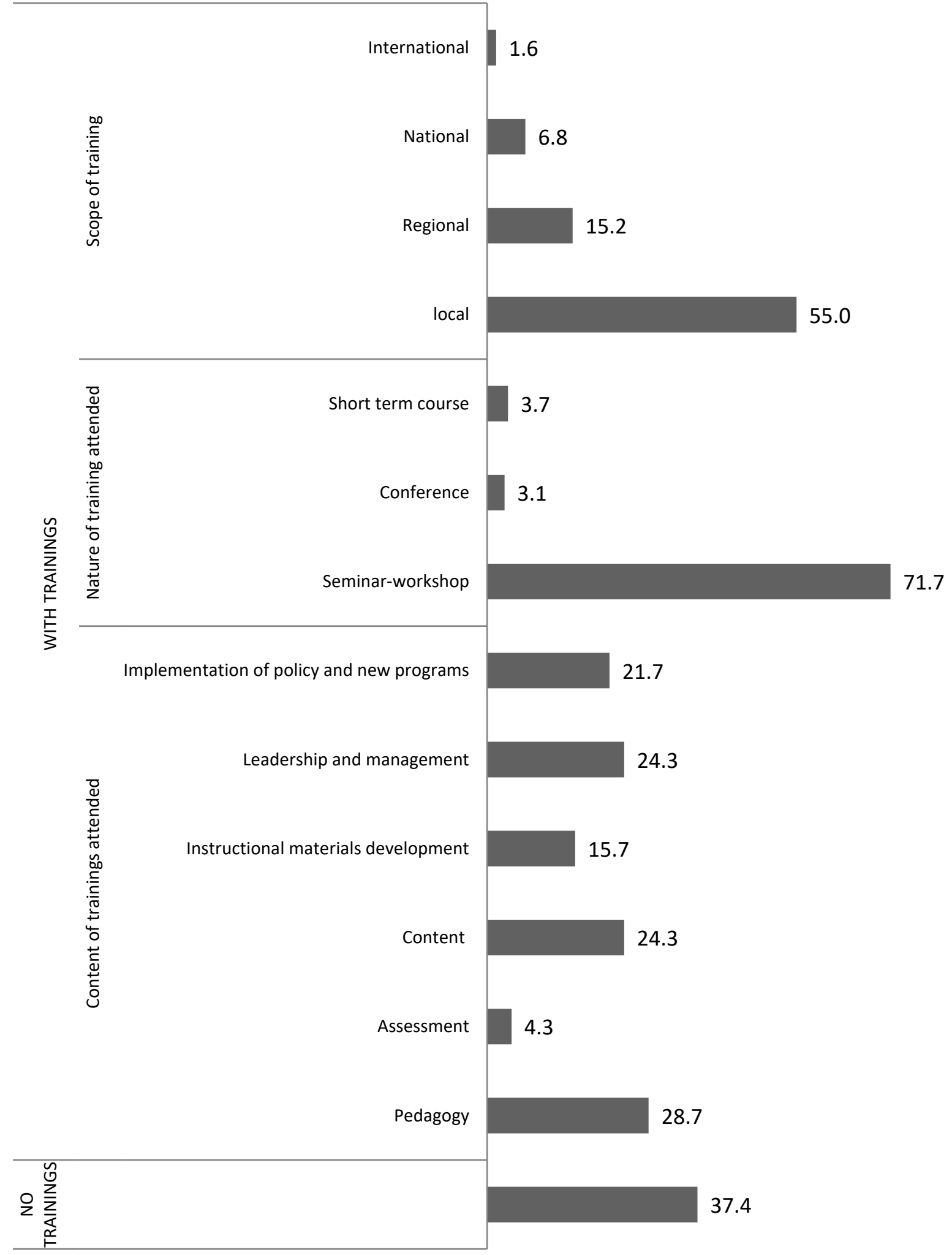

Figure 4.2. Percent distribution of teacher participants as to their in-service training.

As to the nature of training attended the majority teacher participants attended seminar-workshop (71.7\%). The majority teacher participants attended local (55.0\%) training like in their school, district, or division. This finding implies that very few professionals have or had the opportunity to attend training in the national or international level. Teacher participants attended This publication is licensed under Creative Commons Attribution CC BY. 
training within two-three days conducted locally. This finding supported by Spruijt, A., Leppink, J., Wolfhagen, I., Scherpbier, A., Van Beukelen, P., \& Jaarsma, D. (2014) which state that seminar is a small group teaching-learning (T-L) session in which the participants discuss under the guidance of an expert.

The instructor, the students, preparation, content, group dynamics, course coherence, and facilities are vital factors in seminar learning. The participants preparing the seminar eventually develop competencies like identification of presentable information, its retrieval from the sources of information and organization of the presentable material. Students learn the art of communicating with peers through a short time bound presentation (Gomathi, K. G., Shaafie, I. A., \& Venkatramana, M., 2014).

Teachers' training attended from other institution as to content, nature, and scope of training, design of learning and assessment of learning

The majority of teacher participants $(71.1 \%)$ attended a seminar workshop, this implies that the training attended is not purely a lecture type, but they are also engaged in the learning process. As to the content, most of the training attended are more on instructional materials related $(33.5 \%)$, This implies that teacher participants attended one or more training conducted by the College of Education, Caraga State University, Ampayon, Butuan City, under the extension project of the College, entitled "Teachers Training on Instructional Materials Development and Enhancement of their Research Capability. 


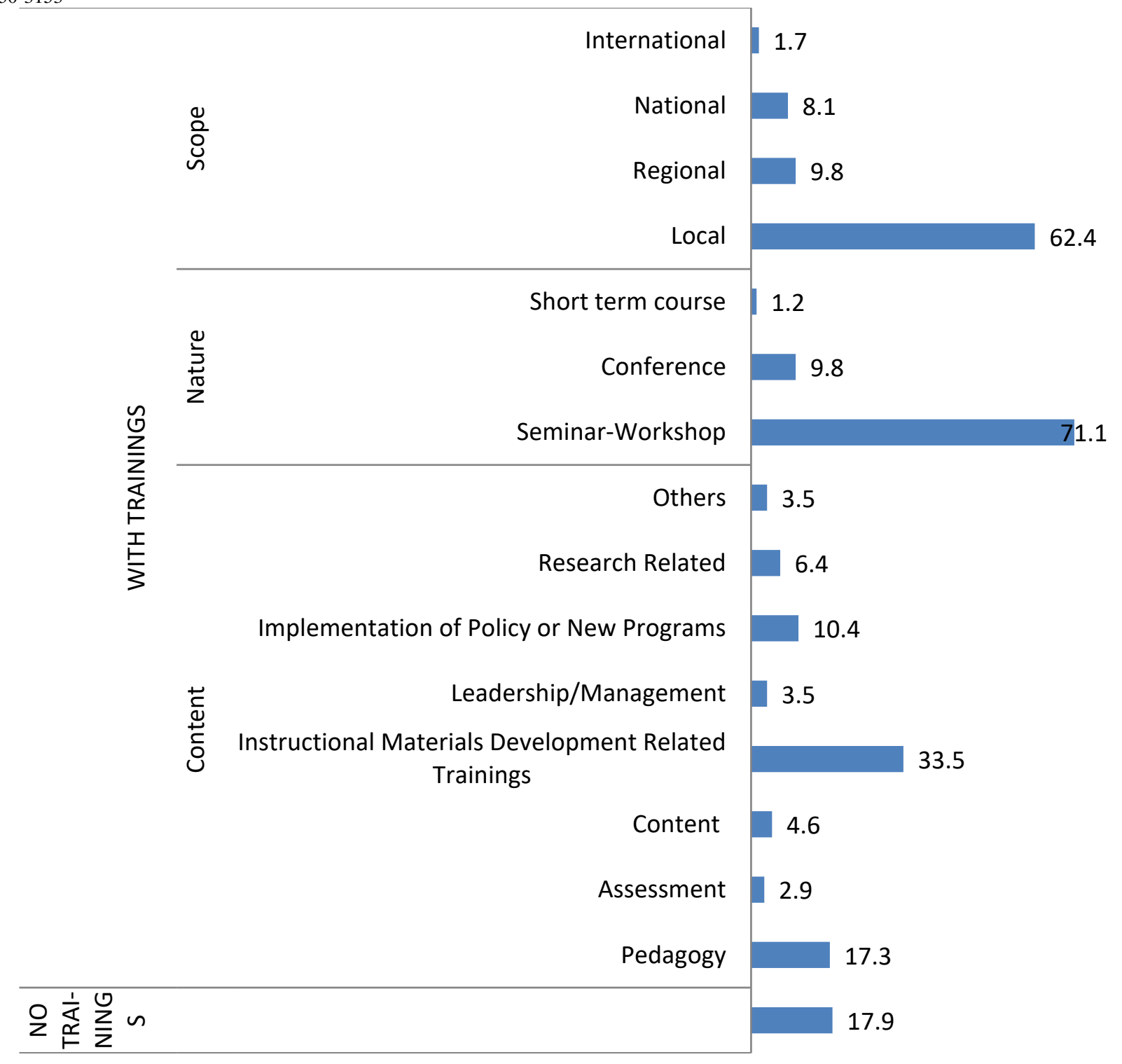

Figure 4.4. Percent distribution of teacher participants as to trainings attended organized by other institutions.

As to the scope, $62.4 \%$ consider the training as local since it is conducted locally at their school, district, and the College of Education. Some $17.9 \%$ of teacher participants had no training from other institutions. The finding further suggests that some teachers had no opportunity to develop their professional career. Johnson and Fargo (2010) echoed these equity challenges, and they note "Teachers in urban schools often experience many distractions occurring in a daily basis and struggle to engage learners who are often distracted by complicated lives outside of school." Thus, challenges in implementing active professional development where teacher professionals can attend to professional development activities extend beyond the school and the classroom. 
Quality of training attended as to the design of learning and assessment of learning

Table 4.2

Quality of Trainings Attended by Teacher Participants as to Design of Learning and Assessment of Learning

\begin{tabular}{ll}
\hline Indicators & Verbal \\
& Mean \\
\hline
\end{tabular}

\section{Design of learning}

The environment in this learning experience was engaging.

4.21

Agree

The purpose of this learning experience was made clear to me.

Learners were full partners with the facilitator in this learning experience.

Agree

The climate in this learning experience can best be described as collaborative.

The facilitator/instructor acted as a rich resource for my learning during this learning experience.

I had flexibility in designing my learning experience (activities, assignments, etc.)

Agree

Agree

4.37

Agree

Agree

\section{Assessment of learning}

I was satisfied with the extent to which I was an active partner in this learning experience.

I knew why the learning strategies were appropriate for the learning goals.

This learning experience was just what I needed given the changes in my life/work.

I feel that my mastery of this material will benefit my life/work.

The knowledge gained in this learning can be immediately applied in my life/work.

This learning experience motivated me to give my best effort.
4.21

Agree

Agree

Agree

Agree

4.24

Agree

As to the quality of training attended from other institution as to the design of learning, teacher participants had agreed to all of the indicators. The indicators on the facilitator/instructor acted as a precious resource for their learning during the learning experience and having flexibility in designing their own learning experience got the highest mean (4.37), implies a significant professional development, where adult needs are considered necessary. Beavers, A., (2009) opined that meaningful professional development involves educators as a whole person their values, beliefs, and assumptions. Just as one should differentiate learning for students in the classroom, professional development for adults must also focus on their individual needs.

As to the assessment of learning, teacher participants had agreed to all indicators. In an adult education orientation, learners freely choose their learning goals and make independent decisions about what, how, and when they want to learn. It is 
base on assumptions that learners are self-directed, learners can make decisions for them, and have a range of life experiences that impact on their learning (Choy \& Delahaye, 2003), due to the high response rating of 4.30 on the indicators; that teacher participants knew why the learning strategies were appropriate for the learning goals,

Among the indicators on the extent to which they are an active partner of the learning experience got the lowest mean rating (4.21). Professional development should create a climate in which participants feel respected; encourage their active participation; build on their experiences; employ collaborative inquiry; guide learning for immediate application; and empower the participants through reflection and action based on their learning (Lawler \& King, 2000, as cited in Lawler, 2009). This further implies that facilitators in training would consider this adult principle and conduct more planning and preparations to meet adult learners need.

Teachers' capability in research-based instructional materials development (RB-IMD) as to needs analysis and development process

Table 4.3

Teachers' Capability on Research-Based Instructional Materials Development as to Needs Analysis and Instructional Materials Development Process

\begin{tabular}{ll}
\hline Indicators & Verbal \\
I was able to: & Mean \\
\hline
\end{tabular}

\section{Needs analysis}

1 identify users and uses of the needs analysis

$3.92 \quad$ Agree

2 describe the target population and the service environment

$3.86 \quad$ Agree

3. identify problems and needs

4.01 Agree

4. assess the importance of the needs

Agree

5. communicate the results to decision makers, users, and other relevant audiences

$3.90 \quad$ Agree

\section{IMs development process}

As I designed IMs I was able to:

1. analyze the "instructional problem" and determine the learning objectives and goals.

2. design a strategic "blueprint" of the materials and methods needed to achieve the learning objectives and goals.

3. develop and create content based on the design blueprint and assemble into an instructional package or curriculum, which is then reviewed and revised based on feedback received. support carrying out the activities and assessments as intended. 

5.
evaluate learner performance or conduct pilot-testing.
3.73
Agree

The teachers' participants had agreed on all indicators. However, there is a high response to the indicator that they can identify problems and needs (4.01). It is essential that teachers learn how to identify the needs of their students and their own professional learning needs. They also need to develop a self-regulatory skill that will enable them to monitor and reflect on the effectiveness of the changes they make to their practice (Timperley, Wilson, Barrar, Fung, 2008).

Moreover, with regards to teachers' capability on research-based instructional materials development (RB-IMD) as to instructional materials development process, data show teacher participants had agreed in all indicators mentioned. Significant findings on the indicator with high response mean rating of 3.84, that as teacher designed IMs, they can analyze the "instructional problem" and determine the learning objectives and goals. The finding implies that teacher participants are doing instructional materials analysis phase before making Instructional Materials. Participants highlighted a research-based IMs development, where the instructional problem is clarified, where the instructional goals and objectives are defined, and the learning environment and where the learner's existing knowledge and skills identified. However, as to the response as they can evaluate learner performance or conduct pilot-testing on the Instructional Materials developed, this has a low rating (3.73) in all the indicators. This further implies that some of the teacher participants fail to accomplish an essential phase in the development of instructional materials, the evaluation phase in which this phase is significant to make sure that IMs developers attain their goals and if the instructional materials able to meet the learner needs (Las Johansen, B. C., Quisumbing, L. A., Funcion, D. G. D., Gotardo, M. A., Verecio, R. L., \& Cinco, J. C., 2017).

Analysis of the correlation between the independent variables and the variables of teachers' research capability on RBIMD

Table 4.1

Results on the analysis of the correlation between the independent variables and the variables of teachers' research capability on RB-IMD in terms of needs analysis and development process.

\begin{tabular}{|c|c|c|c|c|}
\hline \multirow{3}{*}{ Independent Variable } & \multicolumn{4}{|c|}{$\begin{array}{l}\text { Capability on Research-Based Instructional Materials } \\
\text { Development }\end{array}$} \\
\hline & \multicolumn{2}{|c|}{ Needs analysis } & \multicolumn{2}{|c|}{ Development process } \\
\hline & R-coeff & p-value & R-coeff & p-value \\
\hline \multicolumn{5}{|l|}{ In-service training } \\
\hline \multicolumn{5}{|c|}{ The extent of in-service training } \\
\hline Content of training & $0.186^{*}$ & 0.050 & 0.113 & 0.228 \\
\hline Nature of training & $0.192 *$ & 0.040 & 0.133 & 0.157 \\
\hline Scope of training & 0.177 & 0.059 & 0.125 & 0.183 \\
\hline \multicolumn{5}{|c|}{ Training from other institution } \\
\hline Content of training & 0.170 & 0.070 & $0.231 *$ & 0.013 \\
\hline Nature of training & 0.107 & 0.256 & 0.146 & 0.120 \\
\hline Scope of training & 0.157 & 0.094 & $0.236^{*}$ & 0.011 \\
\hline
\end{tabular}




\section{Quality of teachers' training attended}

Design of learning

Assessment of learning
0.048

0.139

0.030
$0.185^{*}$

Teachers' capability on RB-IMD as to needs analysis has a significant positive correlation with the extent of their in-service training as to content and nature of training $(\mathrm{R}=0.186$, $\mathrm{p}$-value $=0.050 \& \mathrm{R}=0.192$, $\mathrm{p}$-value $=0.040$, respectively). The finding implies that those teacher participants who exposed to research related to varied training tend to be more competent in doing RBIMD. Mizell, H. (2010) attests to the importance of this finding, by explaining that Professional development is most effective when it occurs in the context of educators' daily work. She further explains that school-based professional development helps educators analyze student achievement data to immediately identify learning problems, develop solutions, and promptly apply those solutions to address students' needs. Therefore, the extent of teachers' in-service training as to nature and scope significantly contributed to teachers' capability as to needs analysis because teachers benefit most in the in-service training if they can immediately apply what they learn, especially in the classroom setting.

Teachers' capability on RB-IMD as to IMs development process has a significant positive correlation with the quality of teachers' training attended as to content and scope of training $(\mathrm{R}=0.231$, $\mathrm{p}$-value $=0.013 \& \mathrm{R}=0.236$, $\mathrm{p}$-value $=0.011$, respectively $)$. The positive correlation noted in Figure 4.4 as to the training attended with other institutions as to the content of the training attended most of the teacher participants (33.5) attended instructional materials development related training and as to the scope the majority of teacher participants attended seminar-workshop (62.4\%) where they are highly engaged in the learning process. "Professional development is more meaningful if they collaborate from their school, grade, or department" (Porter, A. C., Garet, M. S., Desimone, L. D., Yoon, K. S., \& Birman, B. F. 2000). In research on adult primary education professional development, Smith, C., Hofer, J., Gillespie, M., Solomon, M., \& Rowe, K. (2003) also found that teachers from the same adult basic education program participating together in professional development changed their thinking and acting more after the professional development, as compared to teachers who participated without other teachers from their workplace.

Quality of teachers' training attended as to the design of learning has a significant positive correlation with the teachers' capability on RB-IMD as to needs analysis $(\mathrm{R}=0.187$, $\mathrm{p}$-value $=0.048)$. A positive correlation can be traced to the content of training attended; most of the teacher participants had attended the instructional materials related training, in which they are taught to conduct needs analysis in developing an RB-IMD. The finding further implies that the quality of training attended by teacher participants significantly contribute to their capability in RB-IMD as to the design of learning. As these teachers attend training, they also collaborate with other teachers. Learning Forward (2011) as cited by Killon, J., (2015), opined that teacher collaboration is a robust learning design. This standard emphasizes using active engagement, appropriate learning designs, and application of theories and research on learning. 
Quality of teachers' training attended as to the assessment of learning has a significant positive correlation with the teachers' capability on RB-IMD as to needs analysis and IMs development process $(R=0.202$, p-value $=0.030 \& R=0.185$, $p$-value $=0.049$, respectively). The finding further suggests that the learning experience gained from the training attended is beneficial and is timely to their life and work as a teacher. Since most of the training attended from other institutions are about instructional materials development related, this is essential to the teaching and learning process and with the change of curriculum to K-12 curriculum and with the spiraling progression approach, teachers in the field are in a quandary on what to do. Sowder (2007) maintains that professional growth is characterized or "marked by a change in teachers' knowledge, beliefs, and instructional strategies."

\section{Conclusion and Recommendations}

The teacher participations in seminar-workshop in their school, district and division, the training from other institution about or related to instructional materials development, and the quality of teachers' training attended as to the design of learning and assessment of learning significantly contribute to teachers' capability in research-based instructional materials development as to needs analysis and development process.

Based on the findings, it is recommended to enhance and continue developing teachers' capability in research-based instructional materials development through further training, towards sustainable quality education.

\section{References}

Akyel, A., (1999). Teacher's attitudes toward their job and professional development. Mediterranean Journal of Educational Studies.6(1).

Atilano, M.M. (2018). Educational supervision, Teachers' commitment and performance in selected Higher Education Institutions (HEIs) in the Zamboanga Peninsula. International Review of Social Science, 6 (10).

Barber, M. \& Mourshed, M. (2007). How the World's Best Performing School Systems Come Out on Top. McKinsey \& Company.

Choy, S. C. \& Delahaye, B. L. (2003). Youth learners: The authentic neglected Species learning for an unknown future. In C. Bond \& P. Bright (Eds).

Colclough, C., (2005). Rights, goals, and targets: how do those for education add up?Journal of International Development, 17(1), 101-111.

Falus, Ivans, (2002). The teacher who learns. Iskolakultúra, 2002 (6-7), 76-83.

Garet, M. S., Porter, A. C., Desimone, L., Birman, B. F., \& Yoon, K. S. (2001).What Makes professional development effective? Results from a national sample of teachers. American educational research journal, 38(4), 915-945.

Gomathi, K. G., Shaafie, I. A., \& Venkatramana, M. (2014). Student-led seminars as A teaching-learning method-effectiveness of a modified format. South East Asian J Med Educ, 8, 82-4.

Greenleaf, C. L., Litman, C., Hanson, T. L., Rosen, R., Boscardin, C. K., Herman, J., \& Jones, B., (2011). Integrating literacy and science in biology: Teaching and 
learning impacts of reading professional apprenticeship development. American Educational Research Journal, $48(3)$, 647-717.

Hanushek, E. A., (2003). The Failure of Input-Based Schooling Policies. Economic Journal, 113 (February), F64-F98.

Howard, J., (2007). Curriculum development. Center for the Advancement of

Teaching and Learning. Elon University.

Johnson, C. C., \& Fargo, J. D. (2010). Urban school reform enabled by

Transformative professional development: Impact on teacher change and student

learning of science. Urban Education, 45(1), 4-29

Killion, J., (2015). High-quality collaboration benefits teachers and students. The Learning Professional, $36(5), 62$.

King, K. P., \& Lawler, P. A. (2003). Trends and issues in the professional development of teachers of adults. In K. P. King \& P. A. Lawler (Eds.), New Perspectives on designing and implementing professional development of teachers of adults. San Francisco: Jossey-Bass.

Knowles, M. S., Holton III, E. F., \& Swanson, R. A. (2012). The adult learner. Routledge.

Las Johansen, B. C., Quisumbing, L. A., Funcion, D. G. D., Gotardo, M. A., Verecio, R.L., \& Cinco, J. C., (2017). Views and preference in the development of Instructional Materials for IT courses in the case of BSIT students. International Journal of Recent Advances in Multidisciplinary Research, Vol. 24.

Mizell, H., (2010). Why Professional Development Matters. Learning Forward. 504 South Locust Street, Oxford, OH 45056.

Petrie, K., \& McGee, C., (2012). Teacher Professional Development: Who Is the Learner?. Australian Journal of Teacher Education, 37(2), 59-72.

Spruijt, A., Leppink, J., Wolfhagen, I., Scherpbier, A., Van Beukelen, P., \& Jaarsma, D., (2014). Investigating teaching performance in seminars; A questionnaire study with a multi-level approach. BMC medical education, 14(1), 203.

Sowder, J. T., (2007). The mathematical education and development of teachers. In F. K. Lester (Ed.) Second Handbook of Research on Mathematics Teaching and Learning. Charlotte, NC: National Council of Teachers of Mathematics; Information Age Pub, (pp. 157-224).

Strong, M., Fletcher, S., \& Villar, A. (2004). An investigation of the effects of Teacher experience and teacher preparedness on the performance of Latino students in California. Santa Cruz, CA: New Teacher Center.

Timperley, H., Wilson, A., Barar, H., \& Fung, I. (2008). Teacher professional learning and development. International Academy of Education, (pp. 61-74)

Trotter, Y. D. (2006). Adult Learning Theories: Impacting Professional Development Programs. Delta Kappa Gamma Bulletin, 72(2). 